\title{
Agency and Adaptation: Strategies of Immigrants' Descendants on the Swedish Labor Market'
}

I Pinar Aslan²

Lecturer in social work, University of Gävle, Department of Social Work and Criminology, Sweden

I Nader Ahmadi

Professor in social work, Director General, Swedish Agency for Work Environment Expertise, Sweden

\section{Eva Wikström}

PhD in social work, Senior lecturer, Umeå University, Department of Social work, Sweden

\section{Stefan Sjöberg}

Associate Professor in social work, Senior lecturer, University of Gävle, Department of Social Work and Criminology, Sweden

\begin{abstract}
This article explores how descendants of immigrants in Sweden understand labor market conditions, and how such understandings influence their occupational strategies. We interviewed 21 Sweden-born individuals with non-Western immigrant parents, and identified three strategies based on our analysis of the data: 'choosing' the right job, adapting the habitus, and using cultural capital in flexible ways. The first strategy covers interviewees working in jobs with labor shortages and/or high demand for employees with immigrant background. The second covers interviewees who could learn through failing, with substantial resilience and persistence. The third deals with interviewees who searched for jobs in branches that valued their particular skill set, entailing the importance of being flexible on the labor market.
\end{abstract}

\section{KEYWORDS}

Cultural capital / descendants of immigrants / habitus / labor market / occupation / qualitative interviews / second generation / strategies / work

\section{Introduction}

he educational and occupational trajectories of descendants of immigrants have constituted an important topic for European and American researchers over the past couple of decades. A growing body of literature extensively documents the social and economic disadvantages that migrants' descendants face in Europe and in the U.S. (e.g., Adida et al. 2010; Heath 2010; Karsten 2010). Compared to their majority peers, these

\footnotetext{
${ }^{1}$ You can find this text and its DOI at https://tidsskrift.dk/njwls/index.

${ }^{2}$ Corresponding author: pinar.aslan@hig.se.
} 
individuals are overrepresented in school dropouts and have higher levels of unemployment, lower employment rates, and lower earnings, even after taking sociodemographic characteristics such as education into account (OECD 2017). However, despite lower levels of school performance, descendants of immigrants generally have higher educational aspirations than their native-born peers (cf. Kaya 2018). Nonetheless, research also shows that they are less rewarded for their educational credentials (Behtoui 2012).

According to studies, a non-European, non-Western background is particularly associated with labor market exclusion. For example, Hermansen (2013) shows that in Norway, descendants of immigrants with a non-European background demonstrate a weaker labor market attachment compared to majority peers with a similar socioeconomic background. These findings have also been demonstrated by researchers in Sweden, showing that descendants of non-Western immigrants are particularly disadvantaged on the labor market (Bursell 2014; Jonsson 2007; Statistics Sweden 2010). According to scholars, the factors shaping the labor market exclusion of immigrants' descendants are, among others, social networks (cf. Behtoui 2006), labor market discrimination (e.g., Midtbøen 2016), and negative consequences from parents' social and economic exclusion (Tasiran \& Tezic 2007).

Thus, we know a lot about how and why immigrants' descendants are disadvantaged on the labor market. Less is known, however, about the aspects which shape and contribute to the labor market inclusion of immigrants' descendants. The present study focuses on individuals who have entered and participated on the labor market in Sweden. Learning more about influences on the labor market entrance and participation of immigrants' descendants may contribute to an increased knowledge about the social and economic incorporation of these individuals. Earlier studies examining these aspects highlight the importance of favorable institutional arrangements (Guiraudon 2014), positive influences from family members (Louie 2012), and the support of various powerful social and institutional actors (Portes \& Fernandez-Kelly 2008). Labor market participation of immigrants' descendants is also influenced by individual characteristics, active actions, and decision-making (Crul et al. 2017; Konyali 2017).

Sweden, like many other countries, is characterized by an increasing globalization and internationalization (cf. Olofsson 2018), where labor market conditions are rapidly changing and negative attitudes against non-Western immigrants and their descendants are increasing (cf. Ahmadi et al. 2016). Thus, we need more knowledge about how these individuals understand and approach the labor market. As argued by Olofsson (2018), it is necessary for the social sciences to bring together and make sense of the ways in which social structures and individual biographies intersect. One way of doing this is to focus on how objective opportunities and constraints are subjectively understood and responded to by individuals in their everyday lives. In light of this, the aim of this study was to explore how employed descendants of immigrants in Sweden subjectively understand labor market conditions, and how such understandings influence their occupational strategies.

\section{Labor market conditions for young people of migrant descent}

Labor market participation in Sweden today is characterized by new demands for work skills, an increasing number of atypical jobs, and a more drawn-out school-to-work 
transition (Olofsson 2018). These conditions affect people in general who are entering the labor market, but the labor market opportunities of young people and immigrants are particularly impacted (Schröder 2015). Labor market entry is becoming less linear and more diverse, and young people in Sweden today have a harder time finding a foothold on the labor market compared to a couple of decades ago. The school-towork transition in Sweden is an increasingly drawn-out process, and many young people spend several years in temporary employment and part-time work before obtaining secure employment (Schröder 2015). Some of these challenges relate to the decline of traditional industry and the rise of a more information-intensive and internationalized labor market (Olofsson 2018).

Against this background, young people of migrant descent are in a particularly precarious situation with regard to labor market entry. They are affected by hurdles that negatively influence the labor market participation of young people in general, but they are also subjected to other forms of disadvantage. Having an immigrant background implies disadvantages in addition to those that come with being young and inexperienced on the labor market. Descendants of immigrants in Sweden more often grow up with low-educated and unemployed parents (Crul \& Mollenkopf 2012), have less access to job contacts (Behtoui 2015), and are more often raised in segregated and socioeconomically disadvantaged areas (Olofsson 2018). These areas are, for example, characterized by low levels of education, higher levels of unemployment, and higher poverty and health risks for the people living there (Andersson \& Malmberg 2018). Descendants of immigrants also risk facing discrimination in recruitment processes, which is particularly pronounced against those with a non-Western background (Bursell 2014; Midtbøen 2016).

Earlier studies indicate that the educational aspirations, career decisions, and labor market participation of immigrants' descendants may be related to the disadvantages they face. For example, students with non-European immigrant backgrounds more frequently choose academic studies before vocational, compared to their majority peers on the same performance level (Kilpi-Jakonen 2011). According to Urban (2012), the greater tendencies among these individuals to pursue higher education is a compensation strategy to deal with anticipated labor market discrimination.

Other studies have emphasized that descendants of immigrants have higher educational ambitions than do descendants of native-born with similar socioeconomic backgrounds (Feliciano \& Lanuza 2016; Kaya 2018; Luthra \& Soehl 2015). Some scholars claim that this is related to immigrant parents' class background in the country of origin (Feliciano \& Lanuza 2017). According to these scholars, class-specific knowledge acquired before migration is transmitted from immigrants to their children, also in families with low socioeconomic status in the host country. Kindt (2017), for example, found that descendants of immigrants in Norway with parents of high status before migration enjoyed similar forms of parental support as those of middle-class background. Others have argued that migration in itself becomes a form of capital, since immigrant parents, also those with lower socioeconomic background before migration, believe that the new country entails opportunities for intergenerational mobility (Dreby 2010; Kasinitiz et al. 2008; Louie 2012).

Moreover, the occupational pathways of descendants of immigrants are influenced by an increasingly internationalized labor market. Technological and political connectedness between countries and international migration have increased the European 
labor markets' demand for transnational knowledge, skills, and qualifications, also referred to as 'cultural competence' (Arrighetti et al. 2014; Gerhards \& Hans 2013; Wee 2014). These labor market demands influence the kind of jobs that are frequently available to immigrants' descendants. There is also a growing literature on 'ethnic niching', meaning an increase in ethnically profiled jobs and business sectors (Thomson \& Crul 2007). Earlier, scholars who have focused on ethnic niches have studied the overrepresentation of ethnic minorities in certain jobs or job sectors (cf. Kushnirovich 2010). The concept of 'ethnically profiled jobs' here refers to jobs that are available to members of ethnic minorities in particular due to their ethnic background. These jobs may, for example, be culturally framed or require interaction with immigrant clients and thus so-called cultural competence (Gruber 2016). While some scholars have seen these labor market conditions and demands as opportunities for people of migrant descent to enter and mobilize on the labor market (e.g., Hedberg \& Petterson 2012), others have criticized them for strengthening processes of differentiation between immigrants and native-born (Eliassi 2015). While internationally and ethnically profiled work positions can be due to the choices made by descendants of immigrants, many scholars imply that such choices could be based on having assessed a lack of other options (Konyali 2017).

\section{Relevance of studies conducted in other Nordic countries}

Despite the relatively strong economy of the Nordic region, virtually all Nordic countries tamper with the issue of integrating people with an immigrant background to the labor market (Nordic Council of Ministers 2018). A number of studies show that people with an immigrant background face labor market discrimination in the Nordic countries (Dahl \& Krog 2018; Liebkind et al. 2016; Midtbøen 2016; Quillian et al. 2019). This entails an unequal access to the labor market, which is underlined by studies examining the labor market entry of immigrants' descendants. Studies show that that immigrants' descendants generally have a harder time finding jobs (Hermansen 2013; Nielsen et al. 2003), and that male descendants of immigrants in particular are disadvantaged in terms of finding employment (Gupta \& Kromann 2014).

On the other hand, several studies show patterns of socioeconomic mobility among descendants of immigrants in Nordic countries. Hermansen (2016) presents evidence of clear intergenerational progress in terms of educational attainment and earnings in Norway. These patterns of intergenerational mobility can be seen as a result of the high expectations that immigrant parents have on their children to reach educational and occupational success (cf. Feliciano \& Lanuza 2016). Rytter (2011) discusses how educational and career attainments in Pakistani families in Denmark very often became a 'family project', shaping the educational and occupational ambitions and performance of the Pakistani immigrants' descendants.

Studies also show that the ethnic background of immigrants' descendants shape their labor market participation. For example, Friberg and Midtbøen (2018) introduce the concept of 'ethnicity as skill', and show how employers equate certain ethnicities with particular competences and skills. In another study, Midtbøen and Nadim (2019) show tendencies of ethnic niche formation among highly educated descendants of immigrants in Norway, both among those working in so-called 'mainstream' firms and those in ethnically niched firms. Overall, these studies shed light on some main challenges and 
opportunities faced by immigrants' descendants in the Nordic labor markets. The present study builds on this literature to explore and expand our knowledge of the different strategies used by descendants of immigrants to be included on the labor market.

\section{Theoretical approach}

\section{Using agency to transform the habitus}

In this article, we start from the concept of habitus and cultural capital as developed by Bourdieu (1986; 1990) and other scholars (e.g., Dumais 2002; Jæger \& Breen 2016; Silva 2016; Wacquant 2014). Bourdieu (1999) saw social action as determined by reflexivity and a 'common sense', as well as by structural possibilities and obstacles engraved in individuals' minds and bodies. According to this perspective, an individual action contains of a two-way relationship between objective structures of the social world and the subjective embodiment of these structures. The embodiment of structures is conceptualized as habitus. As explained by Wacquant (2006, p. 268) the habitus not only reproduces social structures but can also be modified and changed:

Habitus is also a principle of both social continuity and discontinuity: continuity because it stores social forces into the individual organism and transports them across time and space; discontinuity because it can be modified through the acquisition of new dispositions and because it can trigger innovation whenever it encounters a social setting discrepant with the setting from which it issues.

Analyzing processes of change in the habitus among descendants of immigrants is of high relevance, since these individuals are often socially mobile (see, e.g., OECD 2017). Despite being born in Sweden, descendants of immigrants are generally raised by parents with a limited history of knowledge and experience of the Swedish labor market and institutions affiliated with it, such as the educational system (Crul et al. 2017). As mentioned earlier, they more often grow up with parents who are excluded from the labor market (Crul \& Mollenkopf 2012) as well as living in segregated and disadvantaged neighborhoods (Andersson \& Malmberg 2018), and therefore have less contacts and ties to the labor market (Behtoui 2006). Broadly speaking, then, descendants of immigrants may be considered less naturally familiar with labor market entry and participation, in comparison to their majority peers. As stressed by Bourdieu (2000), individuals who end up in less familiar situations will have to overcome their incorporated habitus and be more reflexive and conscious in their decision-making.

Throughout his academic career, Bourdieu attached great importance to the subconscious aspects of the habitus (e.g., Bourdieu \& Passeron 1979), partly as a response to the theoretical traditions, which he thought disregarded the subconscious elements of human practice, and partly to highlight the ways in which hidden societal relations of power and subordination manifest themselves in individuals' everyday practices. In light of this intense focus on subconscious practices, the classical critique against Bourdieu is that he is deterministic in his explanations of human action (see, e.g., Butler 1997).

However, later texts by Bourdieu (e.g., 2008) more clearly define habitus as both intentional and subconscious in practice. In these texts, a distinction is made between 
situations that come naturally to individuals, and situations and contexts that demand higher degrees of agency, including planning and calculation of action (Bourdieu \& Wacquant 1992). When people are familiar with a situation, they rarely think about what they do. In more unfamiliar situations, however, it is necessary to be active and plan to manage the situation (Bourdieu 2000), which may or may not result in a crossing of boundaries between social strata.

From this viewpoint, individuals from socially and economically disadvantaged backgrounds have to act according to 'common sense', and transgress their incorporated habitus, in order to achieve their goals on the labor market (Bourdieu 1990). In applying his theoretical tools to a self-analysis of his own career, Bourdieu (2008) explains that the crossing of boundaries between social strata requires a transformation of the habitus. Such a transformation may be more or less radical, and sometimes results in a so-called 'cleft habitus', meaning a struggle to balance between formerly and newly acquired elements of the habitus.

In light of this theoretical framework, we look at the conscious strategies of immigrants' descendants and how they transform the habitus to better fit requirements of the labor market. We find the concept of habitus to be a useful framework to analyze our data, since we are interested in how individual dispositions of action relate to the structures of the labor market, and how the habitus might be both reproduced and transformed. Descendants of immigrants may not only plan their actions and work out strategies to deal with institutional and structural obstacles (Keskiner \& Crul 2017) but may also come across unexpected contingencies along the way which they learn to make use of (cf. Bourdieu 2008).

\section{Using cultural capital on the labor market}

The concept of habitus is interwoven and integrated with the concept of capital. Capital refers to types of resources (economic, cultural, social) that are available to an individual (Bourdieu 1986). In this article, we focus on cultural capital, that is, the type of symbolic resources that become valuable in relation to labor market participation for the interviewees. Cultural capital can come in an embodied form, as acquired ways of thinking, behaving, and acting that help individuals advance in vital societal institutions such as the labor market. It can also come in an institutionalized form, as knowledge, skills, and qualifications used to gain ground on the labor market and acquire a specific job or enter particular sectors (Bourdieu \& Passeron 1979; Broady 1998; Dumais 2002; Lamont \& Lareau 1988). In addition to such immaterial forms of symbolic resources, cultural capital may also come in a material shape, as objects that verify the skills and qualifications of individuals, for example, as educational diplomas (Jæger \& Breen 2016). Moreover, the values ascribed to these resources are always relational to the context in which they are used, and the value system of a specific labor market sector determines what is considered capital in that particular sector (cf. Nohl et al. 2014).

Against this background, the demand for employees with an immigrant background and/or cultural competence in certain jobs or job sectors implies the use of ethnicity as a symbolic resource to gain ground on the labor market (Zhou 2013). Simultaneously, such occurrences shed light on the unequal access to the labor market more generally for people of varied ethnic backgrounds. In addition to working in the traditional 'ethnic 
niches', scholars have also shown how immigrants' descendants are actively recruited to jobs with ethnic profiles, meaning, for example, that they either work in internationally operating firms (Konyali 2017) or with job tasks that require contacts with immigrant clients (Gruber 2016). For immigrants' descendants then, having an immigrant background may be a burden in entering a job sector where jobseekers with foreign-sounding names risk being discriminated against, while it may be a resource in sectors or jobs that value the immigrant-specific experiences of immigrant employees.

\section{Material and Methods}

\section{The sample}

This article is based on qualitative, semi-structured interviews with 12 female and nine male descendants of immigrants in Sweden, aged 25-35 years. A qualitative research design is useful when the research aim is related to people's subjective perceptions and understandings. We recruited participants by advertising for descendants of immigrants in various Facebook groups, and by placing an advertisement in a cost-free newspaper, Metro, which reaches approximately 1.2 million individuals in mid- and southern Sweden.

Since we were interested in individuals who had entered and participated on the labor market, we used a strategy of purposeful sampling (Patton 2015). We searched for participants who had been gainfully employed for at least six months, who were aged 25-35, and who had been born in Sweden to parents from non-European, non-Western countries. The majority of the individuals who reached out to us had parents from the Middle East $(n=20 / 21)$. This did not come as a surprise, since many 25 to 35 -year-old descendants of immigrants in Sweden today have parents who migrated to Sweden from the Middle East during the 1980s and early 1990s.

At the time of the interview, most of our interviewees had been employed for at least three years, although our criteria for the minimum time of employment was six months. Seventeen had completed a university degree, while three had completed a vocational education and one had a secondary educational degree. The reason for this imbalance in our sample in terms of educational background may be that we searched for individuals who had been gainfully employed for at least six months, and most secure jobs in Sweden today require a higher educational degree (Olofsson 2018). Another possible reason is that individuals who have obtained a university degree may have put more thought into labor market entry and career mobility (cf. Urban 2012) and may therefore be more interested in taking part in a study about labor market participation. Moreover, the first author of this article advertised for interviewees, and conducted the interviews. The possibility of attracting people who are highly educated might increase when a person who represents an academic institution calls for participants who are established on the labor market.

The fact that our sample includes many people with higher education means that our results are mainly applicable to individuals with university diplomas. On the other hand, the sample happened to be rather varied with respect to parents' educational and occupational background, and so studying these individuals has provided us with empirical insights in relation to exercising individual agency and exceeding parents' 
socioeconomic status. All interviewees were employed in jobs corresponding with their educational degrees and qualifications. The range of professions in the sample was rather varied, from social workers, a career coach, a psychologist and teachers, to a lawyer, an engineer, pharmacists, a financial controller, and a café owner. Moreover, the interviewees worked in the private, as well as public sector. Thus, the results are not specific for particular professions.

A few of our interviewees' parents had a vocational or university degree and were employed in jobs that matched their education, some were low-educated and employed in low-skilled monotonous jobs, while others were low-educated and long-term unemployed. 'Low-educated' here refers to parents who had dropped out in elementary school or had never attended school at all. Many of the low-educated parents who were employed worked in sectors which the interviewees themselves had aimed to avoid, such as the restaurant business. As mentioned, many of our interviewees had managed to exceed their parents' socioeconomic status. Parents, regardless of socioeconomic background, can thus affect their children's possibilities of social mobility in multiple ways (see, e.g., Dreby 2010). However, here we are not focusing on parental influences on the interviewees' possibilities to enter the labor market. Rather, we are focusing on how they make use of their individual agency and develop strategies to enter and participate on the labor market. Since our sample mainly contained individuals who had already obtained university diplomas, they can be regarded as having entered the labor market from more or less the same starting point, with their immigrant background as a commonly shared aspect.

Another notable attribute of our sample is that an overwhelming majority of our interviewees grew up in segregated areas of Sweden, meaning immigrant-dense areas that are characterized by various types of social problems, for example, lower student performance and higher levels of unemployment (cf. Ekholm \& Dahlstedt 2019). Growing up in these areas entails a limited access both to job contacts and to knowledge about labor market entry and participation. The interviewees were spread over urban and suburban areas in a number of small, medium-sized and larger Swedish cities, located in the northern, mid- and southern parts of Sweden. More specifically, the interviewees were from Borås $(n=1)$, Borlänge $(n=4)$, Falun $(n=2)$, Gothenburg $(n=1)$, Malmö $(n=1)$, Norrköping $(\mathrm{n}=2)$, Sandviken $(\mathrm{n}=1)$, Stockholm $(\mathrm{n}=5)$, Sollentuna $(\mathrm{n}=1)$, Södertälje $(\mathrm{n}=1)$, Uppsala $(\mathrm{n}=1)$, and Umeå $(\mathrm{n}=1)$.

\section{The role of the researcher(s)}

It is possible that the interviewees talk differently to a highly educated researcher about issues related to labor market participation than they would with peers. A mitigating circumstance with regard to this is that the interviewer here also had a Middle Eastern background and was around the same age as the interviewees. As argued by Fontana and Frey (2008), sharing a background with the interviewees may be an advantage during the interview process. For example, the interviewees in the current study sometimes expressed an expectation that the interviewer understood what they had been through by saying things like 'I'm sure you've experienced this too'. Such expectations indicate a sense of connection with the interviewer, and might help the interviewees to feel at ease and talk more freely about certain issues.

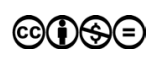




\section{Data collection}

Data were gathered during September 2015 and January 2016 in places and settings decided by the interviewees. The interviews were carried out with the help of an interview guide, including open questions formulated on the basis of dominant themes in earlier research and the theoretical approach. These questions involved, among other things, the interviewees' perceptions and experiences of entering the labor market, their occupational aspirations, their assessments of the possibility to fulfill these aspirations, and actions taken to achieve various labor market goals. The interviews were between 30-90 minutes long (most of them lasted for at least more than an hour) and transcribed into written text.

The research design was based on a strategy of abduction (Dubois \& Gadde 2002), and the open questioning resulted in some new areas of interest. For example, it became clear throughout the interviews that the interviewees' understandings of labor market conditions and demands influenced their orientations towards labor market entry and participation. In light of this, we focused explicitly on the understanding of such conditions and the ways in which these conditions influenced the interviewees' occupational pathways and strategies.

Fourteen of the interviews were conducted over the telephone or the Skype video conference program, and the remaining seven were performed face-to-face. Although some scholars have expressed concerns regarding digital interviewing, we considered it a helpful tool in relation to many aspects. First, offering various options of interviewing techniques increases interviewees' motivation to participate in a study, and thereby contributes to the variation of the sample. Second, it speeds up the data collection process, since it entails flexibility in terms of geographical location and time (Fontana \& Frey 2008). Finally, digital interviewing is a more environmentally friendly alternative when interviewing interviewees who live far from the researcher. Some scholars have criticized the milieu of digital interviewing, arguing that it is different from the natural environment of a face-to-face-interview. However, through recent technological developments, interviews through Skype and other technological tools enable environments that are quite similar to those of face-to-face-interviews (Iacono et al. 2016).

\section{Analytical procedure}

The analytical procedure of this study took an abductive thematic approach, meaning that we started with a preliminary understanding of the problematics but were open and flexible to the emergence of new themes during the data collection process (cf. Rambaree \& Faxelid 2013). We formulated an interview guide with question areas derived from earlier research and the theoretical tools on labor market participation of descendants of immigrants. These questions were, among other things, about their family and social background, social contacts, perceptions of searching for and being at work, and workrelated aspirations and attainments. During and after the data collection, more specific themes as well as new (unexpected) themes emerged. We used version 7.5.4 of the ATLAS.ti qualitative data software package to code and structure our empirical material into themes. During this process, we kept a codebook, including the frequency, meaning, and relation between codes, to create a network view (Friese 2014). 


\section{Ethical considerations}

Approval from the Swedish Regional Ethical Review Board (registration number 2015/025) was obtained before initiating the data collection. Ethical guidelines from the Swedish Research Council were followed throughout the research process, including sending out a letter prior to data collection informing the interviewees of their rights and the conditions of the study. Among other things, we took measures to ensure the anonymity of the interviewees and informed them of their right to withdraw from the study at any time during the research process.

\section{Results}

The results presented below are thematized in three main strategies, based on our analysis of the empirical data. The strategies identified were used by our interviewees to enter and participate on the labor market: 1) 'choosing' the right job, 2) adapting the habitus, and 3) using cultural capital in flexible ways. These strategies and approaches were not specifically linked to particular professions but formed in relation to how the interviewees understood labor market conditions, including challenges and opportunities related to their immigrant background. In the first two sections, we use the concept of habitus as a theoretical tool to analyze our data. In the first section, we focus on individuals who are in 'familiar' situations, thus using already-existing dispositions of action. The second section deals with individuals who find themselves in 'unfamiliar' situations, and thus have to learn how to adapt and change their existing habitus. In the third, and final section, we use the concept of cultural capital to analyze how the interviewees use their competence and skills to enter and participate on the labor market.

\section{'Choosing' the right job}

Assessing an opportunity to turn what might be a disadvantage into an advantage, some of our interviewees actively chose sectors in which they thought that their individual background could be presented as a 'selling point'. This strategy appeared among interviewees who had entered labor market sectors, which offered them good opportunities to get a job and/or advance. These opportunities were assessed in relation to their immigrant background, and general labor market shortages in the branch. Moreover, this approach could be traced to the interviewees' general anticipations of discrimination or unequal treatment on the labor market, as illustrated by the following quotation from a 27-year-old male teacher [IP10]:

IP10: We don't have that privilege, and it became clear when it was time to choose a career track ... You sort of lower the bar ... even if you have a degree, you might not get the job you're qualified for because of your ethnic background ... so, I asked around and sought info, and I understood that not enough people are becoming teachers ... and with my immigrant background, it would be easy to find a job, I mean in these schools with a lot of immigrant kids ... very few people want to work there, and people like me are used to fill those shortages. 
These findings can be analyzed using the concept of habitus, which is based on a two-way relationship between social and institutional conditions, and the way people subjectively understand options, opportunities, and obstacles (Bourdieu 1999). If individuals assess that they have limited access to the labor market in general but vast opportunities in specific jobs or job sectors, they may be inclined to go for those jobs in order to minimize the risk of failure. Thus, the occupational pathways of immigrants' descendants reflect their assessments of labor market conditions, against which they orientate their actions. This is further illustrated in the following extract from an interview with a 32-year-old male interviewee [IP5], who had chosen to pursue a teaching career in a school district where many immigrant students attend:

\begin{abstract}
IP5: And then, I thought "Teacher ... there's a shortage of teachers ... maybe I should go for that." ... Partly I was like "It's a female-dominated sector, and as a man, it's easier to find a job as a teacher," and partly also "If I have a teaching degree, it will be very easy to find a job.”... And partly because I speak Arabic and that is quite valuable around here.
\end{abstract}

The quote from our interviewee above [IP5] may also be understood in relation to the labor market conditions that generally face men with an immigrant background. According to Bursell (2014), there is generally a higher degree of labor market discrimination against men with an immigrant background in Sweden than against their female counterparts. Looking for jobs in sectors with labor shortages may be a common approach for people generally who are excluded from the labor market. Nonetheless, descendants of immigrants may have to relate to additional disadvantages simultaneously, and so this strategy can have special relevance for this group of individuals. Moreover, Baert et al. (2015) showed that job applicants with foreign-sounding names in Belgium particularly benefitted from applying for vacant job positions that are hard to fill, since the demand for labor supply decreases recruiters' tendencies to discriminate against immigrants.

For some interviewees, finding a job in a sector with a shortage of labor supply and a demand for employees with an immigrant background was less of a calculated plan and more a question of contingent experiences. Bourdieu (1990) considers the occurrence of contingent experiences as central to explaining differences in life outcomes between individuals of similar socioeconomic backgrounds. According to Bourdieu (2008), individuals from disadvantaged social backgrounds may obtain intergenerational mobility partly because they come across opportunities that they manage to take up and use to their advantage. A 26-year-old male interviewee [IP17] exemplified such contingent experiences. While he did not plan to search for jobs in sectors where his immigrant background was perceived as a valuable asset, he learned afterwards how to make use of such conditions:

IP17: Before becoming a social worker, I felt like my immigrant background was a disadvantage when searching for a job ... I always felt that I had to overcompensate to prove that I'm competent. But after becoming a social worker, there were lots of job opportunities out there. In this branch, I can present myself as someone who understands the clients' background ... who can instill trust and speak with them in their language. So, now I feel like my immigrant background is an advantage. 
The actions of our interviewees show that they develop a 'feel for the game' in learning how to make use of their ethnic background as an asset on the labor market. This is congruent with what Bourdieu (1999) discusses in terms of playing by the rules of the game, implying that different labor market sectors provide distinct conditions for entry and participation. Thus, the ethnic backgrounds of descendants of immigrants may be a positive symbolic resource in some jobs or job sectors, while it is a negative one in others. Some of our interviewees explained and justified their current pathways in relation to facing ethnic penalties. While some of these interviewees had actively considered these conditions before choosing to apply for a certain job, for others, it was a question of unexpected contingencies. Regardless, these interviewees perceived their labor market entrance as easy and straightforward, because their personal backgrounds matched the conditions and demands of a particular job or labor market sector.

\section{Adapting the habitus}

In the previous section, we demonstrated how interviewees benefitted from ending up in the 'right' job with regard to labor market conditions, which here related to their immigrant background and labor shortages. In this section, we focus on interviewees who were employed in branches where they had not been able to use such personal or structural characteristics as symbolic resources. Being in highly competitive job sectors, these interviewees had dealt with hurdles by developing alternative strategies to find jobs and obtain career advancement. The most distinct characteristic in the pathways of our interviewees was that they had failed many times but had actively sought information in the process of failing in order to become better and eventually overcome the challenge, indicating a trial-and-error approach. In accordance with the concept of habitus, descendants of immigrants who are in unfamiliar situations may use various approaches of learning while doing to enter the labor market and advance at the workplace (see, e.g., Rezai 2017). One of our male interviewees [IP20], a 25-year-old purchasing analyst at a private company, exemplified such findings:

IP20: When it was time to search for a job, it was like being punched in the face ... I sent out CVs like crazy ... I think I went to 70 job interviews ... But at every job interview, I learned. When they told me "You aren't the right person for us," I always asked "Okay, but could you please tell me what I did wrong?", and then I learned something new for the next time ... and after a while, I think I became a pro, because suddenly a lot of job offers started to come.

As illustrated by the interview extract above, some salient characteristics among our interviewees were resilience, endurance, and persistence, underlined by their continued efforts despite facing hurdles on the way (cf. Crul et al. 2017). Rather than giving up, they took active measures to learn what recruiters wanted to see and hear from job applicants and used this acquired knowledge to get ahead. This strategy of learning and developing along the way is conceptualized by Bourdieu (2008) as an important determinant of intergenerational social mobility. Some of our interviewees employed this strategy by starting out in lower job positions and working their way up through gradual achievements. This finding is exemplified by a 35 -year-old female interviewee [IP12]: 
IP12: I started as just an external consultant but saw it as a way to get a foothold. They were shutting down ... and moving to India. During this time ... I did a lot of cover for people who were on sick leave ... I jumped in, worked really hard, and learned how to do the job. And after about seven-eight months, I was the one they let travel to India to make the whole changeover - which is a big thing, and weird, because I wasn't even a regular employee at first.

It is crucial to note that this strategy of learning along the way and of transforming the habitus to better fit labor market demands is not exclusive to descendants of immigrants. Rather, it may be a common strategy for people, especially young individuals, aiming to enter the labor market and achieve their career goals. However, combined with the general fear of facing ethnic penalties, our interviewees frequently expressed a need to overcompensate for these disadvantages with extra exertions and a high ability to learn and adapt.

Bourdieu (2008) implies that the process of learning along the way is important for a person to cross boundaries between social strata. In order to cross these boundaries, however, the habitus must undergo some form of transformation, meaning that individuals from disadvantaged backgrounds undergo changes in aspects such as their behavior and language (Bourdieu 2008). This process of change was more or less evident among our interviewees, which according to Bourdieu (2008) may result in a so-called 'cleft habitus', that is, a struggle to balance between earlier and newly acquired dispositions of actions. However, some of our interviewees experienced a divergence with past dispositions of action rather than a cleft habitus. This is illustrated by the following quotation from an interview with a 28-year-old female interviewee [IP22]:

IP22: I'm on a completely different level today ... and nowadays, when they [her old friends] come up to me ... I'm embarrassed. For example, when I had an in-service training for my care homes. We're standing outside ... and up comes one of those old acquaintances, with baggy pants and everything, and he's like "Heeeey NN!" ... I was so ashamed. I told them "It's an old patient of mine.” I didn't know how to handle it ... It was horrible.

Our interviewee [IP22] described a process of change resulting in weakened relations with earlier acquaintances and friends. Thus, by using strategies of adapting and learning along the way, the habitus may transform in more extended and unintended ways, including changes of behavior, tastes, language, and preferences. As discussed by Lee and Kramer (2013), undergoing a shift in the habitus influences how well socially mobile individuals manage to interact with their new environments, while also affecting their relations to previous communities. Here, we show how descendants of immigrants may experience difficulties to reconcile the newly acquired elements of their habitus with old ones, leading them to distance themselves from and feel alienation toward their contexts of origin (cf. Schneider \& Lang 2014).

\section{Using cultural capital in flexible ways}

The third and final strategy presented in this article deals with interviewees who had acquired qualifications that made them attractive to recruiters. This strategy, like 
the previous two, is concerned with the extent to which the habitus corresponds to the conditions and demands of the labor market, including the acquisition of assets conceptualized as cultural capital in certain labor market sectors. The interviewees showed a great deal of flexibility in their job search process, for example, by changing direction if they came across too many challenges in a certain area. This degree of flexibility often emerged from experiences of ethnic discrimination in certain labor market sectors, and included a strategy of reorienting themselves toward other sectors where the evaluation of their skill set could neutralize potentially negative influences of their ethnicity.

Some of the interviewees had acquired skills that were common in certain job sectors but extraordinary in others, and the relative evaluation of such skills influenced their occupational pathways. Obtaining these skills was generally not part of some previously worked-out plan, but rather a resource they made use of a posteriori, after understanding its value in relation to the sector. The experiences of a 35-year-old female interviewee [IP12] exemplify such findings. Her original aspiration was to work in accountancy, in which she had a degree, but after having a hard time finding a job in the business sector, she changed her plans and ended up in the IT industry:

IP12: I applied for many jobs [as an accountant], and was called in for some interviews, but never got a chance to go further ... Many times, I felt like it went really well, but I still didn't get it, and I thought "Was it because of my ethnic background?” ... But I don't want to be the one who says it, you know. But today, looking at how I am treated ... it's different. Because I have this SAP competence in business systems, it's a coveted skill set in the IT industry ... so, I get many job offers ... it's different now, it's all based on my merits, not on my gender or ethnic background.

These findings demonstrate two main aspects: first, that descendants of immigrants may perceive a need for extraordinary qualifications in order to avoid negative influences of their ethnicity in the job-search process, and second, that their occupational pathways may take unexpected turns depending on the skills they have acquired. As highlighted by Bourdieu, the value ascribed to a symbolic resource is relational to the context in which it is used. Above, we can see that our interviewee (IP12) changed branches in order for her skill set to become a symbolic resource and overshadow potential impacts of ethnicity. Our analysis here is underlined by earlier research reporting a compensatory behavior among descendants of immigrants who perceive a need for qualifications and skills to counteract anticipated labor market challenges (Urban 2012).

Moreover, our results suggest that, in order to manage new, unfamiliar contexts, social agents who must adapt and reorientate themselves (cf. Schneider \& Lang 2014). Many of our interviewees took alternative paths which, although most of them ultimately brought contentment, were influenced by anticipated difficulties and experienced disadvantages on the labor market. This may also be the case for young people of nativeborn descent who enter a changing and more demanding labor market. Nevertheless, the ethnic penalties faced by immigrants' descendants may put these individuals in a more demanding position and therefore require higher degrees of agency, creativity, and flexibility. In light of our results, it may be concluded that the exercise of agency is related to processes of adapting to challenges and conditions. 


\section{Discussion and conclusion}

The aim of this study was to explore how employed descendants of immigrants in Sweden understand labor market conditions, and how such understandings influence their occupational strategies. We identified three main strategies in our data that answer this research aim: 'choosing' the right job, adapting the habitus, and using cultural capital in flexible ways. These strategies include various approaches used by descendants of immigrants to enter and participate on the labor market.

The study makes theoretical, as well as empirical contributions to the literature. We use the concepts of habitus and cultural capital to show patterns of social continuity and discontinuity. On the one hand, we illustrate how an individual's habitus can lead him/ her into certain, familiar settings on the labor market, and on the other hand, how the process of meeting new, unfamiliar contexts may result in a transformation of the habitus. While some interviewees were employed in jobs or job sectors in which their ethnic background could be used as a positive symbolic resource, thus being able to draw from an already existing habitus, others tried to cross boundaries by adapting their habitus, and by using their accumulated cultural capital.

As for its empirical contribution, our study adds to the increasing body of research dealing with the labor market participation and social mobility of descendants of immigrants in Western countries (e.g. Keskiner \& Crul 2017; Louie 2012). As shown in earlier studies examining influences on the occupational attainments of immigrants' descendants (Keskiner \& Crul 2017; Rezai 2017; Waldring et al. 2014), our interviewees were observant and prone to take advantage of 'fortunate' events. Many of them grew up with parents who were unable to provide them with practical support in entering the labor market, and had been raised in segregated, socioeconomically disadvantaged neighborhoods. This may require a great need for individual efforts and conducive, personal characteristics to enter the labor market and achieve their career goals. The findings presented in this study underline an influence of labor market conditions in the ways in which descendants of immigrants orient themselves on the labor market, and how such conditions may trigger the level and form of individual agency exercised.

Many of the disadvantages at stake here, is the ethnic preference discrimination facing the interviewees when they approach the labor market. Our findings relate to what scholars have conceptualized as ethnically niched jobs, meaning that the labor market participation of immigrants and their descendants is strongly impacted by their ethnicity or immigrant background (Gruber 2016; Konyali 2007; Light 2007). In this paper, we saw that descendants of immigrants may understand the labor market as an exclusivist and conditionalized place, in which they are generally disadvantaged, but which they could adapt to. One aspect of this might be to accept a job offer even though one is overqualified for the work tasks (cf. Behtoui 2012). Thus, it is important to acknowledge that the flexible or creative strategies shown in this study may function as an adaptation to an inferior position.

Moreover, these findings may be compared to studies demonstrating that the labor market participation of immigrants' descendants is influenced by demand for cultural competence and transnational knowledge (Hedberg \& Pettersson 2012; Konyali 2017). The tendencies of immigrants and their descendants to go into businesses or jobs that value their ethnicity or immigrant background have been critically reviewed by many scholars, who have analyzed these processes in light of structural inequalities (Volery 2007). 
Our findings illustrate that descendants of immigrants understand the labor market as an ethnically segregated space, where these descendants are allowed into some jobs or job sectors but have to struggle to enter others. These interpretations clearly influenced their approach to the labor market, which developed in the light of perceiving and anticipating ethnic penalties and a risk of exclusion (cf. Konyali 2017). Thus, our results mainly shed light on the interaction between ethnicity and habitus in relation to labor market entry and -participation. This does not mean that class status is unimportant. On the contrary, many of the approaches and strategies illustrated in this article, such as finding jobs in branches with a demand for labor supply, may not be exclusive to immigrants' descendants, but also relevant for explaining how young people of working-class background generally cope with labor market obstacles. Having already undergone higher education, however, where it is probable that most tensions with regard to class mobility occurs (cf. Lee \& Kramer 2013), most of our interviewees mainly expressed difficulties related to their ethnicity, and justified their strategies by referring to such difficulties. These qualitative findings underline that immigrants' descendants experience obstacles that go beyond class background, and illuminate how such obstacles may be understood and managed.

Since our sample included individuals in very diverse jobs and labor market sectors, we have not been able to analyze whether the strategies used by descendants of immigrants prevail and develop in specific ways in relation to particular professions. Further research may address this relationship in more detail by focusing on several individuals employed in the same branch, and on how inherent and taken-for-granted rules, beliefs, and values in that branch may affect people's strategies to enter and participate in it.

\section{References}

Adida, C. L., Laitin, D. D., \& Valfort, M.-A. (2010). Identifying barriers to Muslim integration in France, Proceedings of the National Academy of Sciences of the United States of America 107: 22384-22390. doi: http://doi.org/10.1073/pnas.1015550107.

Ahmadi, F., Palm, I., \& Ahmadi, N. (2016). Mångfaldsbarometern 2016 (FOU Report 44). Gävle: Gävle University Press, Available at http://hig.diva-portal.org/smash/get/ diva2:1085307/FULLTEXT01.pdf.

Andersson, E., \& Malmberg, B. (2018). Segregation and the effects of adolescent residential context on poverty risks and early income career: a study of the Swedish 1980 cohort, Urban Studies 55(2): 365-383. doi: http://doi.org/10.1177/0042098016643915.

Arrighetti, A., Bolzani, D., \& Lasagni, A. (2014). Beyond the enclave? Break-outs into mainstream markets and multicultural hybridism in ethnic firms, Entrepreneurship and Regional Development 26(9-10): 753-777. doi: http://doi.org/10.1080/08985626.2014.992374.

Baert, S., Cockx, B., Gheyle, N., \& Vandamme, C. (2015). Is there less discrimination in occupations where recruitment is difficult? Industrial and Labor Relations Review 68(3): 467-500. doi: http://doi.org/10.1177/0019793915570873.

Behtoui, A. (2006). Unequal Opportunities. The Impact of Social Capital and Recruitment Methods on Immigrants and their Children in the Swedish Labour Market (Doctoral dissertation). Linköping University, Linköping. doi: http://doi.org/10.1111/j.11217081.2004.00281.x.

Behtoui, A. (2012). Incorporation of children of immigrants: the case of descendants of immigrants from Turkey in Sweden, Ethnic and Racial Studies 36(12): 2141-2159. doi: http:// doi.org/10.1080/01419870.2012.696667. 
Behtoui, A. (2015). Social capital. In: C. Westin (Ed.), The Integration of Descendants of Migrants from Turkey in Stockholm: The TIES Study in Sweden (pp. 57-67), Amsterdam: Amsterdam University Press. doi: http://doi.org/10.5117/9789089648419.

Bourdieu, P. (1986). The forms of capital. In: J. Richardson (Ed.), Handbook of Theory and Research for the Sociology of Education (pp. 241-258), Westport CT: Greenwood. doi: http://doi.org/10.1002/9780470755679.ch15.

Bourdieu, P. (1990). The Logic of Practice, Cambridge: Polity Press.

Bourdieu, P. (1999). Praktiskt förnuft. Bidrag till en handlingsteori [Practical reason. On the theory of action], Göteborg: Daidalos.

Bourdieu, P. (2000). Pascalian Meditations, Stanford: Stanford University Press.

Bourdieu, P. (2008). Sketch for a Self-Analysis, United Kingdom: Polity Press.

Bourdieu, P., \& Wacquant, L. (1992). An Invitation to Reflexive Sociology, Chicago: University of Chicago Press.

Bourdieu, P., \& Passeron, J. C. (1979). The Inheritors. French Students and their Relation to Culture, Chicago: University of Chicago Press.

Broady, D. (1998). Kapitalbegreppet som utbildningssociologiskt verktyg [The concept of capital as a tool for the sociology of education] (Skeptron 15), Uppsala: Uppsala universitet.

Bursell, M. (2014). The multiple burdens of foreign-named men-evidence from a field experiment on gendered ethnic hiring discrimination in Sweden, European Sociological Review 30: 399-409. doi: http://doi.org/10.1093/esr/jcu047.

Butler, J. (1997). Excitable Speech: A Politics of the Performative, London: Routledge.

Crul, M., Keskiner, E., \& Lelie, F. (2017). The upcoming new elite among children of immigrants: a cross-country and cross-sector comparison, Ethnic and Racial Studies 40(2): 209-229. doi: http://doi.org/10.1080/01419870.2017.1245432.

Crul, M., \& Mollenkopf, J. (2012). The Changing Face of World Cities. Young Adult Children of Immigrants in Europe and the United States, New York: Russell Sage.

Dahl, M., \& Krog, N. (2018). Experimental Evidence of Discrimination in the Labour Market: Intersections between Ethnicity, Gender and Socio-Economic Status, European Sociological Review 34(4): 402-417. doi: http://doi.org/10.1093/esr/jcy020.

Dreby, J. (2010). Divided by borders. Mexican migrants and their children, Berkeley, CA: University of California Press.

Dubois, A., \& Gadde, L. E. (2002). Systematic combining: an abductive approach to case research, Journal of Business Research 55(2): 553-560. doi: http://doi.org/0.1016/S01482963(00)00195-8.

Dumais, S. A. (2002). Cultural capital, gender, and school success: the role of habitus, Sociology of Education 75(1): 44-68. doi: http://doi.org/10.2307/3090253.

Ekholm, D., \& Dahlstedt, M. (2019). Social exclusion and multi-ethnic suburbs in Sweden. In The Routledge Companion to the Suburbs (pp. 163-172). Available at http://urn.kb.se/ resolve?urn=urn:nbn:se:liu:diva-151369.

Eliassi, B. (2015). Constructing cultural Otherness within the Swedish welfare state: the cases of social workers in Sweden, Qualitative Social Work 14(4): 554-571. doi: http://doi. org/10.1177/1473325014559091.

Feliciano, C., \& Lanuza, Y. R. (2016). The immigrant advantage in adolescent educational expectations, International Migration Review 50(3): 758-792. doi: http://doi.org/10.1111/ imre.12183.

Feliciano, C., \& Lanuza, Y. R. (2017). An immigrant paradox? Contextual attainment and intergenerational educational mobility, American Sociological Review 82(1): 211-241. doi: http://doi.org/10.1177/0003122416684777.

Fontana, A., \& Frey, J. H. (2008). The interview: from neutral stance to political involvement. In: N. K. Denzin \& Y. S. Lincoln (Eds.), Collecting and Interpreting Qualitative Material (pp. 115-160), California: Sage. 
Friberg, J. H., \& Midtbøen, A. H. (2018). Ethnicity as skill: Immigrant employment hierarchies in Norwegian low-wage labour markets, Journal of Ethnic and Migration Studies 44(9): 1463-1478. doi: http://doi.org/10.1080/1369183X.2017.1388160.

Friese, S. (2014). Qualitative Data Analysis with ATLAS.ti (2nd edition), London: Sage.

Gerhards, J. \& Hans, S. (2013). Transnational human capital, education, and social inequality. Analyses of international student exchange, Zeitschrift für Soziologie 42(2): 99-117. doi: http://doi.org/10.1515/zfsoz-2013-0203.

Gruber, S. (2016). Cultural competence in institutional care for youths: experts with ambivalent positions, Nordic Social Work Research 6(2): 89-101. doi: http://doi.org/10.1080/ 2156857X.2015.1109541.

Guiraudon, V. (2014). Economic crisis and institutional resilience: the political economy of migrant incorporation, West European Politics 37(6): 1297-1313. doi: http://doi.org/10. 1080/01402382.2014.929335.

Gupta, N. D., \& Kromann, L. (2014). Differences in the labor market entry of second-generation immigrants and ethnic Danes, IZA Journal of Migration 3(16). doi: http://doi. org/10.1186/s40176-014-0016-5.

Heath, A. (2010). Main determinants of educational and labour market outcomes. In: Equal Opportunities? The Labour Market Integration of the Children of Immigrants (pp. 115-127), Brussels: OECD. doi: http://doi.org/10.1787/g21201964-en.

Hedberg, C., \& Petterson, K. (2012). Disadvantage, ethnic niching or pursuit of a vision? Motives of immigrant women care entrepreneurs in the ageing Swedish society, Journal of International Migration \& Integration 13(4): 423-440. doi: http://doi.org/10.1007/ s12134-011-0217-1.

Hermansen, A. S. (2013). Occupational attainment among children of immigrants in Norway: bottlenecks into employment - equal access to advantaged positions, European Sociological Review 29(3): 517-534. doi: http://doi.org/10.1093/esr/jcr094.

Hermansen, A. S. (2016). Moving up or falling behind? Intergenerational socioeconomic transmission among children of immigrants in Norway, European Sociological Review 32(5): 675-689. doi: http://doi.org/10.1093/esr/jcw024.

Iacono, V. L., Symonds, P., \& Brown, D. H. K. (2016). Skype as a tool for qualitative research interviews, Sociological Research Online 21(2): 12. doi: http://doi.org/10.5153/sro.3952.

Jæger, M. M., \& Breen, R. (2016). A dynamic model of cultural reproduction, American Journal of Sociology 121(4): 1079-1115. doi: http://doi.org/10.1086/684012.

Jonsson, J. O. (2007). The farther they come, the harder they fall? First- and second-generation immigrants in the Swedish labour market, Proceedings of the British Academy 137: 451-505. doi: http://doi.org/10.5871/bacad/9780197263860.003.0011.

Karsten, S. (2010). School segregation. In: Equal Opportunities? The Labour Market Integration of the Children of Immigrants (pp. 193-210), Brussels: OECD. doi: http://doi. org/10.1787/9789264086395-en.

Kaya, G. (2018). Aspirations, capital and identity. Four studies on the determinants of life chances for young Swedes with an immigrant background (Lund Dissertations in Sociology), Lund: Lund University.

Keskiner, E., \& Crul, M. (2017). How to reach the top? Fields, forms of capital, and strategies in accessing leadership positions in France among descendants of immigrants from Turkey, Ethnic and Racial Studies 40(2): 283-300. doi: http://doi.org/10.1080/0141987 $\underline{0.2017 .1245435 .}$.

Kilpi-Jakonen, E. (2011). Continuation to upper secondary education in Finland: children of immigrants and the majority compared, Acta Sociologica 54(1): 77-106. doi: http://doi. org/10.1177/0001699310392604.

Kindt, M. T. (2017). Innvandrerdriv eller middelklassedriv? Norsk Sosiologisk Tidsskrift 1(01): 71-86. doi: http://doi.org/10.18261/issn.2535-2512-2017-01-05. 
Konyali, A. (2017). International opportunities on the way up: alternative career paths of descendants of migrants from Turkey in the field of professional business services, Ethnic and Racial Studies 40(2): 264-282. doi: http://doi.org/10.1080/01419870.2017.1245430.

Kushnirovich, N. (2010), Ethnic niches and immigrants' integration, International Journal of Sociology and Social Policy 30(7/8): 412-426. Doi: http://doi.org/ 10.1108/01443331011060751.

Lamont, M., \& Lareau, A. (1988). Cultural capital: allusions, gaps and glissandos in recent theoretical developments, Sociological Theory 6: 153-168. doi: http://doi.org/ $10.2307 / 202113$.

Lee, E. M., \& Kramer, R. (2013). Out with the old, in with the new? Habitus and social mobility at selective colleges, Sociology of Education 86(1): 18-35. doi: http://doi. org/10.1177/0038040712445519.

Liebkind, K., Larja, L., \& Brylka, A. A. (2016). Ethnic and gender discrimination in recruitment: experimental evidence from Finland, Journal of Social and Political Psychology 4(1): 403-426. doi: http://doi.org/10.5964/jspp.v4i1.433.

Light, I. (2007). Women's economic niches and earnings inferiority: the view from the ethnic economy, Journal of Ethnic and Migration Studies 33(4): 541-557. doi: http://doi. org/10.1080/13691830701265412.

Louie, V. (2012). Keeping the Immigrant Bargain: The Costs and Rewards of Success in America, New York: Russell Sage.

Luthra, R. R., \& Soehl, T. (2015). From parent to child? Transmission of educational attainment within immigrant families: methodological considerations, Demography 52(2): 543-567. doi: http://doi.org/10.1007/s13524-015-0376-3.

Midtbøen, A. H. (2016). Discrimination of the second generation: evidence from a field experiment in Norway, Journal of International Migration and Integration 17(1): 253-272. doi: http://doi.org/10.1007/s12134-014-0406-9.

Midtbøen, A. H. \& Nadim, M. (2019). Ethnic niche formation at the top? Second-generation immigrants in Norwegian high-status occupations, Ethnic and Racial Studies 42(16): 177-195. doi: http://doi.org/10.1080/01419870.2019.1638954.

Nielsen, H. S., Rosholm, M., Smith, N., \& Husted, L. (2003). The school-to-work transition of 2 nd generation immigrants in Denmark, Journal of Population Economics 16(4): 755-786. doi: http://doi.org/10.1007/s00148-003-0164-z.

Nohl, A. M., Schittenhelm, K., Schmidtke, O., \& Weiss, A. (2014). Work in Transition: Cultural Capital and Highly Skilled Migrants' Passages into the Labour Market, London: University of Toronto Press. doi: http://doi.org/10.3138/9781442668737.

Nordic Council of Ministers. (2018). State of the Nordic Region 2018, Copenhagen. doi: http://doi.org/10.6027/NORD2018-001.

OECD (2017). Catching Up? Intergenerational Mobility and Children of Immigrants, Paris: OECD. doi: http://doi.org/10.1787/9789264288041-en.

Olofsson, J. (2018). Ungas etableringsvillkor och arbetslivets förändringar - några utgångspunkter [Conditions for the establishment of young people - some premises]. In: J. Olofsson \& F. Wikström (Eds.), Unga inför arbetslivet - om utanförskap, lärande och delaktighet, (pp. 15-44), Lund: Studentlitteratur.

Patton, M. Q. (2015). Qualitative Research and Evaluation Methods (4th edition), London: Sage.

Portes, A., \& Fernandez-Kelly, P. (2008). No margin for error: educational and occupational achievement among disadvantaged children of immigrants, Annals of the American Academy of Political and Social Science 620(1): 12-36. doi: http://doi.org/ $10.1177 / 0002716208322577$.

Rambaree, K. \& Faxelid, E. (2013). Considering abductive thematic network analysis with ATLAS-ti 6.2. In: N. Sappleton (Ed.), Advancing Research Methods with 
New Technologies (pp. 170-186), Hershey PA: IGI Global. doi: http://doi.org/ 10.4018/978-1-4666-3918-8.ch010.

Rezai, S. (2017). Self-made lawyers? Pathways of socially mobile descendants of migrants from Turkey in Europe, Ethnic and Racial Studies 40(2): 230-246. doi: http://doi.org/10 $.1080 / 01419870.2017 .1245433$.

Rytter, M. (2011). Money or education? Improvement strategies among Pakistani families in Denmark, Journal of Ethnic and Migration Studies 37(2): 197-215. doi: http://doi.org/ 10.1080/1369183X.2011.521356.

Schneider, J., \& Lang, C. (2014). Social mobility, habitus and identity formation in the Turkish-German second generation, New Diversities 16(1): 89-105. Available at http://newdiversities.mmg.mpg.de/?page id=1790.

Schröder, L. (2015). The labour market. In: C. Westin (Ed.), The Integration of Descendants of Migrants from Turkey in Stockholm. The TIES Study in Sweden (pp. 103-123), Amsterdam: Amsterdam University Press. doi: http://doi.org/10.5117/9789089648419.

Silva, E. B. (2016). Unity and fragmentation of the habitus, Sociological Review 64(1): 166183. doi: http://doi.org/10.1111/1467-954X.12346.

Statistics Sweden (2010). Born in Sweden - but still different? The significance of parents' country of birth (Demographic Report 2010:2), Stockholm: Statistics Sweden.

Tasiran, A., \& Tezic, K. (2007). Early labour-market experiences of second-generation immigrants in Sweden, Applied Economics 39(7): 809-824. doi: http://doi. org/10.1080/00036840500461915.

Thomson, M., \& Crul, M. (2007). The second generation in Europe and the United States: how is the transatlantic debate relevant for further research on the European second generation? Journal of Ethnic and Immigration Studies 33(7): 1025-1041. doi: http://doi. org/10.1080/13691830701541556.

Urban, S. (2012). University education as a compensation strategy among second-generation immigrants, International Migration Review 46(4): 919-940. doi: http://doi.org/10.1111/ imre.12005.

Volery, T. (2007). Ethnic entrepreneurship: a theoretical framework. In: L. P. Dana (Ed.), Handbook of Research on Ethnic Minority Entrepreneurship: A Co-Evolutionary View on Resource Management (pp. 30-41), Cheltenham: Edward Elgar.

Wacquant, L. (2006). Pierre Bourdieu. In R. Stones (Ed)., Key Sociological Thinkers. (pp. 261-278), Houndsmill, Basingstoke, Hampshire, UK: Palgrave Macmillan.

Wacquant, L. (2014). Putting habitus in its place: rejoinder to the symposium. Body \& Society 20(2): 118-139. doi: http://doi.org/10.1177/1357034X14530845.

Waldring, I., Crul, M., \& Ghorashi, H. (2014). The fine art of boundary sensitivity. Successful second generation Turks and Moroccans in the Netherlands, New Diversities 16(1): 71-87. Available at https://research.vu.nl/ws/portalfiles/portal/1105027/ article+in+new+diversities.pdf.

Wee, L. (2014). Language politics and global city, Discourse: Studies in the Cultural Politics of Education 35(5): 649-660. doi: http://doi.org/10.1080/01596306.2014.922740.

Zhou, M. (2013). Ethnic enclaves and niches. In: I. Ness (Ed.), The Encyclopedia of Global Human Migration. doi: http://doi.org/10.1002/9781444351071.wbeghm201. 